\title{
Gastrointestinal Aspects of COVID-19: A Review
}

\author{
Gontar Alamsyah Siregar ${ }^{1}$, Ginanda Putra Siregar ${ }^{2}$, Darmadi Darmadi ${ }^{1 *}$ \\ ${ }^{1}$ Division of Gastroenterohepatology, Department of Internal Medicine, Faculty of Medicine, Universitas Sumatera Utara, \\ Medan, Indonesia; '2Department of Surgery, Faculty of Medicine, Universitas Sumatera Utara, Medan, Indonesia
}

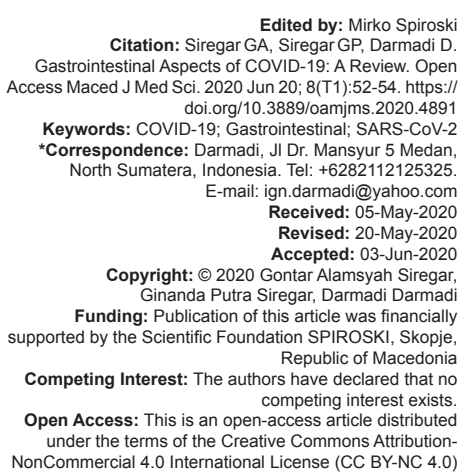
Edited by: Mirko Spiroski
Citation: Siregar GA, Siregar GP, Darmadi D. Citation: Siregar GA, Siregar GP, Darmadi D.
Gastrointestinal Aspects of COVID-19: A Review. Open Access Maced J Med Sci. 2020 Jun 20; 8(T1):52-54. https:// doi.org/10.3889/oamjms.2020.4891
Keywords: COVID-19; Gastrointestinal; SARS-CoV-2 "Correspondence: Darmadi, Jl Dr. Mansyur 5 Medan North Sumatera, Indonesia. Tel: +6282112125325 E-mail: ign.darmadi@yahoo.com Received: 05-May-2020 Revised: 20-May-2020 Accepted: 03-Jun-2020 opyright: $\odot 2020$ Gontar Alamsyah Siregar
Ginanda Putra Siregar, Darmadi Darmad Ginanda Putra Siregar, Darmadi Darmad
Funding: Publication of this article was financially Funding: Publication of this article was financially
upported by the Scientific Foundation SPIROSKI, Skopje, Republic of Macedonia
Reveric rs have declared that no Open Access: This is an open-access article distributed under the terms of the Creative Commons AttributionNonCommercial 4.0 International License (CC BY-NC 4.0)

\begin{abstract}
Coronaviruses commonly cause mild infections, but recently severe acute respiratory syndrome-coronavirus (SARSCoV)-2 caused a pandemic of coronavirus disease 2019 (COVID-19). A total of 3,181,642 cases were confirmed globally. Gastrointestinal tract may be involved in COVID-19 due to the presence of angiotensin converting enzyme-2 (ACE2) and transmembrane protease serine 2 (TMPRSS2) in small intestine and colon which are mandatory for SARS-CoV-2 invasion. A proportion of patients with COVID-19 had gastrointestinal manifestation without respiratory symptoms. Viable virus can also be isolated from feces of patients. Fecal-oral transmission should be considered in controlling disease spreading. Fecal examination may also be considered to diagnose COVID-19, especially in areas with limited personal protective equipment.
\end{abstract}

\section{Introduction}

Coronavirus is enveloped non-segmented positive-sense RNA virus from Coronaviridae family and Nidovirales order. The virus is commonly found in several mammals, including bats [1]. Most of coronavirus infections are mild, but there were several epidemics due to the infection such as severe acute respiratory syndromecoronavirus (SARS-CoV) and Middle-East respiratory syndrome-coronavirus (MERS-CoV). Both epidemics had high mortality rates with MERS-CoV as the highest (37\%) [2]. Recently, an outbreak of coronavirus disease 2019 (COVID-19) due to SARS-CoV-2 occurred at the end of 2019. It started in Wuhan, Hubei, China, and now, it spreads globally, affecting 199 countries [2], [3], [4], [5]. On March 11, 2020, the World Health Organization (WHO) declared it as a pandemic [1].

\section{Epidemiology}

On May $1^{\text {st }} 2020$, there was a total of $3,181,642$ confirmed cases of COVID-19 worldwide with 224,301 death cases. Europe was the region with highest prevalence rate $(1,461,404$ cases) while the USA was the highest prevalence country with $1,035,353$ cases [6]. Most of patients were male with underlying diseases such as diabetes, hypertension, and cardiovascular diseases [2] [7] [8]. The median age of infected patients was 49.0 years [2]. Other study stated that mean age of the patients was 46.14 years and $10.8 \%$ of them had pre-existing liver disease [9]. The most common death leading complication was acute respiratory distress syndrome. The death rate reported from a study by Huang et al. was $15 \%$ [2].

\section{Pathophysiology}

The virus mainly infects respiratory epithelial cells and spreads from human to human through respiratory tract [7]. Gastrointestinal tract is also affected in COVID-19, similar with SARS-CoV and MERS-CoV, but the manifestations are uncommon [1], [3], [10]. Lin et al. found that SARS-CoV-2 could be detected in esophagus, stomach, duodenum, and rectum. The virus was also present in $52.4 \%$ of patients' feces [11]. SARSCoV-2 needs angiotensin-converting enzyme-2 (ACE2) and transmembrane protease serine 2 (TMPRSS2) to enter host cells [1], [2], [3], [7], [8], [12], [13]. Both are highly expressed in small intestine and colon, but not in esophagus. This raises probability that the virus can invade through digestive tract. The invasion causes the development of gastrointestinal manifestations [3], [7]. After binding with ACE2, the virus enters host cell. Viral RNA then integrates into host cell DNA. This process initiates viral protein synthesis and assembly 
of new viruses. This new viruses may invade other cells or released into body fluid in respiratory and gastrointestinal tract [7]. As the role of ACE2 is to mediate inflammation, the infection causes damage in ACE2 receptor, increases in inflammation, damages in mucosa, and triggers diarrhea [12], [14]. In addition, viral invasion causes inflammatory response and imbalance of intestinal microorganism which further damages the digestive system and manifested as gastrointestinal symptoms [8], [13]. The effect of gut-lung axis is also suspected to play an important role in the interaction between respiratory and gastrointestinal manifestations through the common mucosal immune system [8]. A study by Xiao et al. proved that gastrointestinal epithelium of patients with COVID-19 suffered from damage based on endoscopy findings. The damage was observed in esophagus, stomach, duodenum, and rectum. Viral RNA was found in esophageal mucosa but not viral nucleocapsid, indicating that the viral invasion was absent in esophagus due to the absence of ACE2 [7]. ACE2 is also detected in hepatocytes and cholangiocytes so it is possible that liver is involved with SARS-CoV-2 infection. However, the effect of medications, including antibiotic and experimental antiviral, must also be in concern as the aggravating factors of liver damage along with other underlying comorbidities. However, the binding efficiency is thought to be stronger for SARS-CoV-2 compared to other coronavirus. A literature stated that binding affinity of SARS-CoV-2 is $73 \%$ stronger than SARS-CoV. This explains the high transmission rate of SARS-CoV-2 [12] [13].

\section{Clinical manifestations}

Classical manifestations of COVID-19 are fever, cough, dyspnea, and myalgia which indicate droplet as the main mode of transmission of the disease [2], [3], [5], [8], 10], [13]. In MERS-CoV or SARS-CoV infections, gastrointestinal manifestations were found in $20 \%-25 \%$ of patients [2], [10], [12]. Cheung et al. reported a cumulative prevalence of gastrointestinal manifestation in COVID-19 patients as much as $17.6 \%$ while Pan et al. reported a higher rate (20.5\%) [1], [8]. Diarrhea was found in $1-3.8 \%$ of patients with COVID-19 while nausea and vomiting were found in $10.1 \%$ and $3.6 \%$ of patients, respectively [3]. Other study reported that anorexia was the most common gastrointestinal manifestation $(26.8 \%)$ followed by diarrhea (12.5\%) and nausea/vomiting (10.2\%) [1]. In a study by Pan et al., anorexia was the most common gastrointestinal symptom (78.6\%), followed by diarrhea (34\%), vomiting (3.9\%), and abdominal pain (1.9\%) [8].

Jin et al. reported that gastrointestinal manifestations were found in $11.4 \%$ of patients with COVID-19 and $28 \%$ of patients with gastrointestinal manifestations did not have respiratory symptoms.
Furthermore, they had more severe disease course compared to those without gastrointestinal manifestations [9]. Another study reported a higher rate of gastrointestinal manifestations in COVID-19 patients. A total of $61.1 \%$ of patients had gastrointestinal manifestations which consisted of diarrhea (24.2\%), nausea $(17.9 \%)$, vomiting $(42.2 \%)$, and impaired liver function (32.6\%) [11]. Various degrees of liver damage had been reported in COVID-19 patients. Total bilirubin level raised in $10 \%$ of patients while ALT level rose in $16 \%-35 \%$ of patients. Elevated AST was observed in $21 \%$ of patients and alkaline phosphatase was generally normal [12].

\section{Auxiliary examinations}

Real-time reverse transcriptase-polymerase chain reaction (RT-PCR) of nasopharyngeal swab is used to confirm the diagnosis of COVID-19 [4], [5]. Other specimens also showed positive result with bronchoalveolar lavage fluid held the highest positive rate $(93 \%)$, followed by sputum $(72 \%)$, nasal swabs (63\%), fibrobronchoscope brush biopsy (46\%), pharyngeal swab (32\%), feces $(29 \%)$, and blood (1\%) [4]. A meta-analysis reported that the prevalence of positive stool viral RNA was $48.1 \%$ [1]. The accuracy of SARS-CoV-2 detection from feces is comparable with nasopharyngeal swab. It can be suggested that the diagnosis of COVID-19 can be performed from fecal specimen, particularly in areas with limited personal protective equipment [5], [15]. From chest computed tomography, one can find ground-glass opacity [2], [5], while X-rays showed bilateral lung involvement in $98 \%$ of patients. From laboratory examination, $45 \%$ had white blood cell count between 4000 and $10,000 / \mathrm{mL}, 69 \%$ had procalcitonin level of $<0.1 \mathrm{ng} / \mathrm{mL}$, and more than a half patients had lymphopenia. Critical patients showed elevated proinflammatory cytokines, leading to a condition called cytokine storm [2]. The virus might be found in feces from day 1 to 12 of infection [7]. The potential of fecaloral transmission is present since SARS-CoV-2 is still detected in feces even after the virus has been cleared from respiratory tract [1], [3], [7], [13]. The presence of viable virus in feces makes it possible for the disease to spread through stool contaminated hand, food, and water. It is in concordance with the viability of virus in several environments [5], [12], [15]. The virus was still found in feces for a mean of 27.9 days after first symptom onset compared to 16.7 days in respiratory samples [15]. However, the presence of virus in feces was not associated with gastrointestinal manifestations, disease severity, and antiviral treatment [4], [5], [15]. Prevention of fecal-oral transmission should be taken into consideration to prevent further spreading of the disease [7], [10]. 


\section{Conclusion}

COVID-19 is now a pandemic with increasing prevalence and mortality rates. The presence of ACE2 and TMPRSS2 in gastrointestinal tract makes it possible for SARS-CoV-2 to invade through gastrointestinal tract and elicits manifestations. Anorexia and diarrhea are the most common gastrointestinal tract in COVID19 patients. Viable virus is also detected in feces of patients even though it has been cleared from respiratory tract. Fecal examination can be a candidate of diagnostic testing, especially in area with limited personal protective equipment. Further, consideration is mandatory regarding fecal-oral transmission of COVID-19.

\section{References}

1. Cheung KS, Hung IF, Chan PP, Lung K, Tso E, Liu R, et al. Gastrointestinal manifestations of SARS-CoV-2 infection and virus load in fecal samples from the Hong Kong cohort and systematic review and meta-analysis. Gastroenterology. 2020;158:S0016-5085. gastro.2020.03.065 https://doi.org/10.1053/j. PMid:32251668

2. Huang $\mathrm{C}$, Wang $\mathrm{Y}$, Li X, Ren L, Zhao J, Hu Y, et al. Clinical features of patients infected with 2019 novel coronavirus in Wuhan, China. Lancet. 2020;395(10223):497-506. https://doi. org/10.1016/s0140-6736(20)30183-5

PMid:31986264

3. $\mathrm{Ng} \mathrm{SC}$, Tilg H. COVID-19 and the gastrointestinal tract: More than meets the eye. Gut. 2020;69(6):973-4. https://doi. org/10.1136/gutjnl-2020-321195

PMid:32273292

4. Wang W, Xu Y, Gao R, Lu R, Han K, Wu G, et al. Detection of SARS-CoV-2 in different types of clinical specimens. JAMA. 2020;323(18):1843-4. https://doi.org/10.1001/jama.2020.3786 PMid:32159775

5. Zhang JC, Wang SB, Xue YD. Fecal specimen diagnosis 2019 novel coronavirus-infected pneumonia. J Med Virol. 2020;92:680-2. https://doi.org/10.1002/jmv.25742

6. World Health Organization. Coronavirus Disease (COVID-19)
Outbreak Situation. Geneva: World Health Organization; 2020. Available from: http://www.covid19.who.int. [Last accessed on 2020 May 01].

7. Xiao F, Tang M, Zheng X, Liu Y, Li X, Shan H. Evidence for gastrointestinal infection of SARS-CoV-2. Gastroenterology. 2020;158(6):1831-3.e3. gastro.2020.02.055

PMid:32142773

8. Pan L, Mu MI, Yang P, Sun Y, Wang R, Yan J, et al. Clinical characteristics of COVID-19 patients with digestive symptoms in Hubei, China: A descriptive, cross-sectional, multicenter study. Am J Gastroenterol. 2020;115(5):766-73. https://doi. org/10.14309/ajg.0000000000000620

PMid:32287140

9. Jin X, Lian J, Hu J, Gao J, Zheng L, Zhang $\mathrm{Y}$, et al. Epidemiological, clinical and virological characteristics of 74 cases of coronavirus-infected disease 2019 (COVID-19) with gastrointestinal symptoms. Gut. 2020;69(6):1002-9.

PMid:32213556

10. Song $Y$, Liu P, Shi XL, Chu YL, Zhang J, Xia J, et al. SARSCoV-2 induced diarrhoea as onset symptom in patient with COVID-19. Gut. 2020;69(6):1143-4. https://doi.org/10.1136/ gutjnl-2020-320891 PMid:32139552

11. Lin $L$, Jiang $X$, Zhang $Z$, Huang $S$, Zhang $Z$, Fanf $Z$. Gastrointestinal symptoms of 95 cases with SARS-CoV-2 infection. Gut. 2020;69(6):997-1001. https://doi.org/10.1136/ gutjnl-2020-321013

PMid:32241899

12. Agarwal A, Chen A, Ravindran N, To C, Thuluvath PJ. Gastrointestinal and liver manifestations of COVID-19. J Clin Exp Hepatol. 2020;10(3):263-5.

PMid:32405183

13. Gu J, Han B, Wang J. COVID-19: Gastrointestinal manifestations and potential fecal-oral transmission. Gastroenterology. 2020;158(6):1518-9. https://doi.org/10.1053/j. gastro.2020.02.054 PMid:32142785

14. Hashimoto $\mathrm{T}$, Perlot $\mathrm{T}$, Rehman $\mathrm{A}$, Trichereau $\mathrm{J}$, Ishiguro $\mathrm{H}$ Paolino $\mathrm{M}$, et al. ACE2 links amino acid malnutrition to microbial ecology and intestinal inflammation. Nature. 2012;487(7408):477-81. https://doi.org/10.1038/nature11228 PMid:22837003

15. Wu Y, Guo C, Tang L, Hong Z, Zhou Dong X, et al. Prolonged presence of SARS-CoV-2 viral RNA in faecal samples. Lancet Gastroenterol Hepatol. 2020;5(5):434-5. https://doi.org/10.1016/ s2468-1253(20)30083-2

PMid:32199469 